\title{
Relationship between QT dispersion and biochemical parameters in Behçet's disease
}

\section{Behçet hastalarında QT dispersiyonunun biyokimyasal parametreler ile ilişkisi}

\author{
Emine Altuntaş ${ }^{1 *}(\mathbb{D})$, Hülya Nazik ${ }^{2}$ (D) , Feride Çoban Gül ${ }^{3}$ (D) Betül Demir $^{4}$ (iD) \\ 1 İstanbul Büyükçekmece Mimar Sinan Devlet Hastanesi Kardiyoloji Bölümü, İstanbul, Turkey \\ ${ }^{2}$ Kahramanmaraş Üniversitesi Tıp Fakültesi Hastanesi Dermatoloji Bilim Dalı, Kahramanmaraş, Turkey \\ ${ }^{3}$ Elazığ Eğitim ve Araştırma Hastanesi Dermatoloji Kliniği, Elazığ, Turkey \\ ${ }^{4}$ Fırat Üniversitesi Tıp Fakültesi Dermatoloji Bilim Dalı, Elazığ, Turkey \\ *Corresponding author: Emine Altuntaş E-mail: emine_altuntas@hotmail.com ORCID: 0000-0001-5887-5422 \\ Received: 18 February 2019 Accepted: 18 May 2019
}

\begin{abstract}
Objective: Ventricular arrhythmia and sudden cardiac death are more frequently in Behçet's disease (BD) patients than normal population. Therefore in this study it was aimed to find out relationship among QT dispersion, Behçet's disease and biochemical parameters related with disease.

Material and Method: The study consisted of 35 patients which diagnosed Behçet's disease (BD) according to international diagnose criteria and 47 healthy controls which were matched with regard to age and gender. 12-channel surface electrocardiography (ECG) was performed to all participants. QT distances, corrected QT (QTc) distances which is calculated by using Bazett formula were calculated. The longest QT, and the shortest QT, the longest QTc, the shortest QTc were found in the ECG. Afterwards QTd and QTcd were calculated. Blood samples were taken from participants after 12 hours fasting.

Findings: The groups were compared in terms of the longest QT-QTc, the shortest QT-QTc, QTd, QTcd. It was seen that there was meaningful difference in terms of the longest QT and QTc (respectively p; 0.004; 0.018). Mean platelet volume (MPV) and albumin were higher in control group while erythrocyte sedimentation rate (ESR) was higher in BH group (respectively $p$; $0.000 ; 0,000 ; 0,002$ ). Additionally there was negative correlation among the longest QT-QTc and ESR, albumin, but there was established positive correlation between the longest QT -QTc and MPV. Statistical results were presented in table 2-3-4.
\end{abstract}

Conclusion: Consequently in this study, it was established that the longest QT and QTc was increased and there was relationship between biochemical parameters and the longest QT-QTC.

Keywords: Behçet's disease, QT distance, arrhythmia

() 2019 by the authors; licensee MEDITAGEM Ltd., Turkey. This article is an open access article distributed under the terms and conditions of the Creative Commons Attribution License (http://creativecommons.org/licenses/by/4.0/). 


\section{öz}

Amaç: Multisistemik vaskülit ile karakterize olan Behçet Hastalığı'nda (BH) ventriküler aritmi ve ani kardiyak ölüm sıklığı normal popülasyona göre daha sık olması nedeni ile bu çalışmada QT dispersiyonu (QTd) ile BH ve hastalık ile ilişkili biyokimyasal parametreler arasındaki ilişkinin ortaya konulması amaçlanmıştır.

Materyal ve metot: Çalışmaya uluslararası sınıflandırma kriterlerine uygun olarak BH tanısı konulmuş 35 hasta ile yaş ve cinsiyet açısından benzer 47 sağlıklı kontrol olgu dahil edildi. Tüm katılımcıların 12 derivasyonlu yüzey EKG'si çekilerek kalp hızı ve QT mesafeleri ölçüldü. Ardından düzeltilmiş QT (QTc) Bazzet formülü ile hesaplandı. Tüm derivasyonlardaki en küçük QT ve QTc mesafesi ile en büyük QT ve QTc mesafesi arasındaki fark alınarak QTd, QTcd hesaplandı.12 saatlik açlık sonrası kan testleri yapılarak kaydedildi.

Bulgular: Gruplar en uzun QT ve QTc, en kısa QT ve QTc, QTd, QTcd değerleri açısından karşılaştırıldı. En uzun QT ve QTc' de istatistiksel olarak fark oluştuğu görüldü ( $p=0,004,0,018)$. Eritrosit sedimantasyon hızı (ESH) Behçet'li grupta kontrol grubuna göre yüksek iken; MPV ve albumin kontrol grubunda daha yüksek ölçüldü ve gruplar arasında anlamlı fark oluştu ( $p=0,002$; 0,$000 ; 0,000$ ). Ayrıca en uzun QT ve QTc ile ESH ve albumin arasında negatif korelasyon olduğu; ortalama trombosit hacmi (MPV) ile pozitif korelasyon olduğu saptandı. İstatistiksel veriler Tablo 2-3-4'te sunuldu.

Sonuç: Bu çalışmada BH'de en uzun QT ve QTc'nin uzadığı ve hastalık ile ilişkili diğer biyokimyasal parametrelerle arasında korelasyon olduğu tespit edilmiştir.

Anahtar kelimeler: Behçet hastalığı, QT mesafesi, aritmi

\section{INTRODUCTION}

Behçet's disease, which was firstly diagnosed by Hulusi Behçet is a chronic multisystemic vasculitis that courses with remission and attacks [1]. The most common findings are eye involvement, recurrent mouth and genital ulcers. In addition, the disease can affect cardiovascular, gastrointestinal, respiratory, urinary and nervous systems $[2,3]$.

Cardiovascular involvement in Behçet's disease is associated with a poor prognosis. Vasculitis underlying of disease affects every type of artery and vein [4]. The arterial involvement is seen more frequently than venous involvement; moreover it causes worse results. Aortic aneurysm, aortic dissection, pulmonary embolism, cardiomyopathy which evolves secondary to Behçet's disease can cause sudden death $[5,6]$.

QT interval represents electrical depolarization and repolarization of the ventricles. The QT interval gives electrical activation of ventricle recovery time which match each derivation. The QT interval varies according to heart rate, age and gender. It can be recalculated according to heart rate. It is called corrected QT (QTc). The QTc can be calculated by using Bazett formula (QTc $=\mathrm{QT}(\mathrm{sec}) / \sqrt{ } \mathrm{RR}(\mathrm{sec})$ ). Upper limit of QTc for male is 440 millisecond (msec) and for women is $460 \mathrm{msec}[7,8]$. Difference between the longest and the shortest QT or QTc defined as QT dispersion (QTd or
QTcd). Increasing in QTd or QTcd can be a sign of ventricular arrhythmias. In Behçet's patients, ventricular arrhythmia and sudden cardiac death are more frequently than normal individuals [3].

\section{MATERIAL AND METHOD}

Study was done between January 2014 and December 2015. Participants were informed about the study and they approved attending to study. The study was approved by local ethical committee. The participants were selected from the patients who applied to cardiology and dermatology outpatient clinic because of various reasons. The study consisted of 35 patients which diagnosed Behçet's disease (BD) according to international diagnose criteria and 47 healthy controls which were matched with regard to age and gender (5). Younger than 18 years patients, with chronic disease except for BD (diabetes mellitus, malignity, cerebrovascular disease, cardiovascular disease, infectious disease, liver and renal failure, dyslipidemia), obeses and antiarrhythmic drugs users were excluded from the study.

Diameters of left and right heart chambers, ejection fraction (EF) were recorded by using 2.5 Mhz transducer of Vivid-3 echocardiography machine. Participants who had moderate and severe valvular heart disease, pulmonary arterial hypertension, $\mathrm{EF}<55 \%$ were excluded. Then exercise stress test was done for investigating ischemia and the participants whose test was negative were accepted to 
study. Age, gender, disease duration of all participants were recorded.

Blood samples were taken from participants after 12 hours fasting. Hemogram was studied by using Beckman Coulter LH 750 autoanalyser; blood glucose and lipid parameters, insulin, albumin levels were studied by using Beckman Coulter DXI 800 autoanalyser. Homeostatic Model Assessment - Insulin Resistance (HOMA-IR) which is indicator of insulin resistance was calculated by the following formula; HOMA-IR= Fasting glucose $(\mathrm{mg} / \mathrm{dL}) X$ Fasting insulin ( $\mathrm{ulU} / \mathrm{mL}$ ) $/ 405$. The HOMA-IR $\leq 2.5 \mathrm{mg} / \mathrm{dL}$ was accepted normal whereas HOMA-IR $>2.5 \mathrm{mg} / \mathrm{dL}$ were accepted as insulin resistance. So, participants whose HOMA-IR levels were higher than $2.5 \mathrm{mg} / \mathrm{dL}$ were excluded from study.

12-channel surface electrocardiography (ECG) was performed to all participants and the longest and the shortest QT were found in the ECG. Then, the longest and the shortest QTC were calculated by using the Bazett formula. Finally, QTd and QTc were calculated and were recorded.

\section{Statistical Analysis}

SPSS V. 17.0 pocket program was used in statistical assessment of data (SPSS Inc, Chicago, Illinois, USA). Categorical variables were summarized as number and per cent whereas continuous variables were summarized as mean standard deviation. Kolmogorov-Smirnov test was used to determine normal distributed data. Non-parametric data were compared with ki-square $\left(x^{2}\right)$ or Mann Whitney $U$ test whereas normal distributed data were compared with Student t test. Spearman correlation analysis was used in assessment of relationship between two continuous variables. $p<0.05$ was our level of statistical significance.

\section{Findings}

The study consisted of 82 participants. There were 35 (42.7\%) Behçet's patients and 47 (57.3\%) controls in the study. Control groups consisted of 25 men (53.2\%) and 22 women (46.8\%) while there was 15 men (42.9\%) and 20 $(57.1 \%)$ in the BD group. Mean age of groups were in BD group 36.23 \pm 10.1 years and in control group 39.02 \pm 3.8 years. There was no significant difference between groups in terms of age and gender (respectively $p$ value $0.354 ; 0.128$ ).

Disease duration of BD group was 9.14 \pm 5.9 years (min-max 1-20). All of patients with BD were in remission. 26 patients (74\%) were used colchicum, 6 patients (17\%) were used azothiopurin and $3(8 \%)$ patients were not use medication in patients with $\mathrm{BD}$. Twelve patients with $\mathrm{BD}$ and 7 participants
Table 1. General characteristics of participants

\begin{tabular}{|c|c|c|c|}
\hline & $\begin{array}{c}\text { Patients with } \\
\text { BD (n=35) }\end{array}$ & $\begin{array}{c}\text { Controls } \\
\text { (n=47) }\end{array}$ & $\boldsymbol{p}$ \\
\hline Age (years) & $36.23 \pm 10.1$ & $39.02 \pm 3.8$ & 0.354 \\
\hline Gender & $\mathrm{F}: 20$ & $\mathrm{~F}: 22$ \\
$\mathrm{M}: 15$ & $\mathrm{M}: 25$ & 0.128 \\
\hline Smoking & 12 & 17 & 0.251 \\
\hline Disease duration (years) & $9.15 \pm 5.18$ & - & - \\
\hline Colchicine & 26 & - & - \\
\hline Azathioprine & 6 & - & - \\
\hline No any medication & 3 & - & - \\
\hline
\end{tabular}

$p$ : When $p<0.005$ was, it was accepted meaningful as statistically. $\mathrm{BD}$; Behçet's disease

in controls group smoked and there was no difference between groups in point of smoking status. Results were summarized in Table 1.

The groups were compared in view of biochemical parameters and hemogram results. Erythrocyte Sedimentation Rate (ESR) was higher In BD group than control group ( $p=0.002)$. Albumin levels and mean platelet volume (MPV) were higher in control group than BD group (respectively $p$ values; $0.000 ; 0.000$ ). There was no statistical difference when groups were compared with regard to other biochemical parameters and hemogram results ( $p>0.05)$.

The results were summed up in Table 2. 
Table 2. Biochemical parameters in patients with Behçet's disease and controls

\begin{tabular}{|c|c|c|c|}
\hline & $\begin{array}{c}\text { BD group } \\
\mathbf{n = 3 5} \\
\text { Mean } \pm \text { SD }\end{array}$ & $\begin{array}{c}\text { Control group } \\
\mathbf{n = 4 7} \\
\text { Mean } \pm \text { SD }\end{array}$ & p $^{*}$ \\
\hline Albumin (g/dL) & $3.9 \pm 0.7$ & $4.5 \pm 0.3$ & 0.000 \\
\hline Total cholestrol (mg/dL) & $189.3 \pm 25.1$ & $197.2 \pm 36.1$ & 0.249 \\
\hline LDL (mg/dL) & $113.3 \pm 22.5$ & $115.1 \pm 33.5$ & 0.770 \\
\hline HDL (mg/dL) & $53.3 \pm 14.1$ & $50.9 \pm 15.4$ & 0.460 \\
\hline Triglycerid (mg/dL) & $130.1 \pm 36.8$ & $157.7 \pm 86.7$ & 0.054 \\
\hline MPV (fL) & $8.2 \pm 0.5$ & $9.9 \pm 1$ & 0.000 \\
\hline CRP (mg/dL) & $0.8 \pm 1.3$ & $0.4 \pm 0.2$ & 0.071 \\
\hline ESH (mm/h) & $15.3 \pm 9.5$ & $10 \pm 3.2$ & 0.002 \\
\hline Fasting blood glucose & $94.94 \pm 7.12$ & $92.23 \pm 7.35$ & 0.099 \\
\hline (mg/dL) & $8.52 \pm 3.32$ & $10.65 \pm 8.91$ & 0.182 \\
\hline Insulin (ulU/mL) & $1.29 \pm 0.5$ & $1.32 \pm 0.5$ & 0.749 \\
\hline HOMA-lR & $60.3 \pm 3$ & $60.72 \pm 5.07$ & 0.526 \\
\hline EF(\%) & $4.38 \pm 0.64$ & $4.57 \pm 0.39$ & 0.207 \\
\hline LVEDD (cm) & $3.39 \pm 0.46$ & $3.57 \pm 0.37$ & 0.961 \\
\hline LVESD (cm) & $3.42 \pm 0.33$ & $351 \pm 0.27$ & 0.536 \\
\hline LA (cm) & & \\
\hline
\end{tabular}

*Student $\mathrm{t}$ test was used in comparison of groups.

$p$ : When $p<0.005$ was, it was accepted meaningful as statistically.

$\mathrm{cm}$ : Centimeter; $\mathrm{dL}$ : deciliter; fL: femtoliter; g: gram; h: hour; mg: miligram;mL: mililiter; mm: milimeter; LDL: Low density lipoprotein; HDL: High density lipoprotein; ESH: Erythrocyte sedimentation rate; CRP: $C$ reactive protein MPV: Mean platelet volüm; SD: Standart deviation; HOMA-IR: Homeostatic Model Assessment - InsulinResistance; EF: Ejection fraction; LVEDD: Left ventricle enddiastolic diameter; LVESD: Left ventricle end systolic diameter

Table 3. QT duration of the groups

\begin{tabular}{|c|c|c|c|}
\hline & $\begin{array}{c}\text { BD group } \\
(\mathbf{n = 3 5 )}\end{array}$ & $\begin{array}{c}\text { Control group } \\
(\mathbf{n = 4 7 )}\end{array}$ & $\boldsymbol{p}$ \\
\hline The longest QT $(\mathrm{msec})$ & $400.71 \pm 22.34$ & $374.67 \pm 21.996$ & 0.004 \\
\hline The shortest QT $(\mathrm{msec})$ & $360 \pm 28.28$ & $338.67 \pm 28.75$ & 0.054 \\
\hline QTd(msec) & $39.29 \pm 12.68$ & $36 \pm 17.23$ & 0.56 \\
\hline The longest QTc $(\mathrm{msec})$ & $445.57 \pm 20.59$ & $428.07 \pm 16.68$ & 0.018 \\
\hline The shortest QTc(msec) & $399.07 \pm 20.35$ & $386.53 \pm 19.27$ & 0.1 \\
\hline QTcd $(\mathrm{msec})$ & $46.21 \pm 18.78$ & $41.53 \pm 20.42$ & 0.52 \\
\hline
\end{tabular}

msec: milisecond; QTd: QT dispersion; QTc: Corrected QT; Qtcd: Corrected QT dispersion

$p$ : When $p<0.005$ was, it was accepted meaningful as statistically.

Echocardiographic results of the groups were compared and there was no statistical difference between groups in point of ejection fractions (EF), left heart chambers. The results were shown in Table 2.

The groups were compared in terms of the longest $\mathrm{QT}$, the shortest QT, QTd, the longest QTc, the shortest QTc, QTcd. Results of BD group were respectively $400.71 \mathrm{msec}, 360$ msec, $39.29 \mathrm{msec}, 445.57 \mathrm{msec}, 399.07 \mathrm{msec}, 46.21 \mathrm{msec}$. Results of control group were respectively $374.67 \mathrm{msec}$, $386.53 \mathrm{msec}, 36 \mathrm{msec}, 428,07 \mathrm{msec}, 386.53 \mathrm{msec}, 41.53$ $\mathrm{msec}$. When statistical analysis was done there was only the longest QT and QTc meaningful difference. The results were summed up in Table 3.
Table 4. Spearman correlation analysis

\begin{tabular}{|c|c|c|c|c|c|}
\hline & $\begin{array}{c}\text { The longest } \\
\text { QT }\end{array}$ & $\begin{array}{c}\text { The longest } \\
\text { QTc }\end{array}$ & Sedimentation & MPV & Albumin \\
\hline $\begin{array}{c}\text { The longest } \\
\text { QT }\end{array}$ & 1 & 0.328 & -0.376 & 0.399 & -0.102 \\
\hline $\begin{array}{c}\text { The longest } \\
\text { QTc }\end{array}$ & 0.328 & 1 & -0.159 & 0.536 & -0.023 \\
\hline
\end{tabular}

QTc: Corrected QT; MPV: Mean platelet volume

MPV, albumin, ESR, the longest QT and QTc were compared with Spearman correlation test.

There was a negative correlation among the longest QT and albumin, ESR whereas there was a positive correlation between the longest QT and MPV. Similar results were obtained with Qtc. The results were summarized in Table 4.

\section{DISCUSSION}

Behçet's Disease can affect every size arteries and veins. Percentage of vascular involvement changes in different studies among 1-38\%. Endothelial dysfunction which occurs in $\mathrm{BD}$ because of perivascular cellular infiltration and immune mediated vasculitis, may result with leaning to thrombosis, stenosis and aneurysm. In BD heart rate variability may be impaired because of increasing in QTd. Therefore, ventricular arrhythmia is more frequent and risk of cardiac death is increased $[5,6]$. Dispersion of ventricular repolarization is accepted as a possible pieces of serious ventricular arrhythmias. In this study, it was revealed that the longest QT, the longest QTc, the shortest QT, the shortest QTc, QTd and QTc were longer in BD group than control group however, the longest QT and QTc were solely significantly difference.

In a study, QT dispersion was evaluated using 12-channel ECG in BD and it was revealed that QTC was longer in BD group than healthy controls. Furthermore it was determined that frequency of ventricular arrhythmia was increased in this study [8]. In a study done by Day et al. was revealed that ventricular tachycardia increased in long QT syndrome patients [9]. Clinical situations such as hypertrophic cardiomyopathy, myocardial infarct, electrolyte imbalance, heart failure, valvular heart disease cause sudden death because of life-threatening arrhythmias. In many studies it was revealed that there was relationship between sudden death and increased QTd [10-14]. It was thought that the increasing in risk of dysrhythmia was due to loss of ventricular homogeneity in myocardial repolarization. Therefore, QTd has been used in various cardiac pathologies to determine fatal arrhythmia risk [15].

Insulin resistance is decrease in insulin activity that is regulates blood glucose level according to the body's need. 
This pathological situation occurs after complex interaction between inflammation and metabolic mediators [16]. In some studies, it was revealed that HOMA-IR level was higher in BD group than control group [17-19]. Doğan et al. investigated preptin and amylin levels in patients with psoriasis, Behçet's disease and healthy controls. There was no significant difference between the BD group and the control group while the HOMA-IR was lower in the psoriasis group than controls [20]. In this study, it was realized that there was no difference between the groups when compared in point of HOMA-IR.

Evaluating the patients with Behçet's disease in terms of mean platelet volume (MPV), there were conflicting results in the literature. In this study, it was found that MPV was lower in BD group than control group. This finding was similar to the result of the study of Lee et al. [21]. In an other study neuthrophil /lymphocyte ratio, platelet/lymphocyte ratio and MPV was investigated in BD group and healthy controls. They found that there was no meaningful difference between groups [22]. Açıkgöz et al. found in their study that MPV was higher in BD patients than controls [23].

Behçet's disease is chronic inflammatory disease. Therefore there were some studies in which high CRP and ESR levels were calculated [24]. In this study, ESR and albumin levels were high in $\mathrm{BD}$ group. However, there was no meaningful difference between groups in point of CRP and that was similar with another study conducted by Özşeker et al. [25].

The longest QT, the longest QTc, sedimentation, albumin were compared with Spearman correlation analysis. There was positive correlation between the longest QTC and the longest QTc, MPV while there was negative correlation with sedimentation and albumin. The longest QT, the longest QTC, sedimentation, albumin were compared with Spearman correlation analysis (Table 4).

Consequently in this study, The longest QT and QTc, the shortest QT and QTc, QTd, QTc were longer in BD group but only there was meaningful difference in point of the longest QT-QTc. In this group of patients, it might be concluded that fatal arrhythmias can be seen more frequently than healthy controls.

\section{Limitation}

In our study patients with BD did not apply to outpatients clinic because of any complains. They applied to our hospital for routine control. 32 patients used antiinflammatory and immunosuppressive medications. The advanced studies which will be made in active phase of disease will contribute to explain relationship between disease and QT dispersion.

\section{DECLARATION OF CONFLICT OF INTEREST}

The authors received no financial support for the research and/or authorship of this article. There is no conflict of interest.

\section{REFERENCES}

1. Valenti S, Gallizzi R, De Vivo D, Romano C. Intestinal Behçet and Crohn's disease: two sides of the same coin. Pediatr Rheumatol Online J, 2017;15:33.

2. Alpsoy E, Akman A. Behçet Hastalığı; Etyopatogenezde Yeni Kavramlar. Türkiye Klinikleri J Int Med Sci, 2007;3:814.

3. Kaya EB, Yorgun $\mathrm{H}$, Akdogan A, et al. Heart-Rate Recovery Index Is Impaired in Behçet's Disease Tex Heart Inst J, 2009;36:282-286.

4. Doss J, England J, Fuchs H, Zaas AK. Coughing up Blood: Behçet's Disease. American Journal of medicine, 2014; 127: 386-389

5. Davatchi F. Diagnosis/Classification Criteria for Behcet's Disease. Pathology Research International, 2012(2012):Article ID 607921.

6. Aktürk E, Yağmur J, Kurtoğlu E et al. Left atrial volume and function in patients with Behçet's Disease assesed by real-time three dimensional echocardiography. Eur. Heart J Cardiovascular İmagining, 2012;13:650-655. (doi: 10.1093/ejechocard/jer301).

7. Dagli N, Turgut B, Tanyildizi R, Kobat S, Kobat MA, Doğdu O. QT interval dispersion in the patients with central serous chorioretinopathy. Int J Ophthalmol. 2015;8:6165.

8. Aytemir K, Ozer N, Aksoyek S Özcebe O, Kabakçı G, Oto A. Increased QT dispersion in theabsence of QT prolongation in patients with Behçet's disease and ventricular arrhythmias. Int J Cardiol 1998;67:171-175.

9. Day CP, McComb JM, Campbell RW. QT dispersion: an indication of arrhythmia risk in patients with long QT intervals. BrHeart J 1990;63:342-344.

10. Helming $\mathrm{H}$, Holm $\mathrm{E}$, Jun $\mathrm{L}$, et al. The prognostic value of QT interval and QT dispersion in all cause and cardiac mortality and morbidity in a population of Danish citizens. EurHeart J 1998;19:1391-1400. 
11. Davey PP, Bateman J, Mulligan IP, Forfar C, Barlow C, Hart G. QT interval dispersion in chronic heart failure and left ventricular hypertrophy: relation to autonomic nervous system and Holtertape abnormalities. BrHeart J 1994;71:268-273. 54

12. Linker NJ, Colonna P, Kekwick CA, Till J, Camm AJ, Ward DE. Assessment of QT dispersion in symptomatic patients with congenital long QT syndromes. Am J Cardiol 1992;69:634-638.

13. Dritsas A, Sbarouni E, Gilligan D, Nihoyannopoulos $P$, Oakley CM. QT interval abnormalities in hypertrophic cardiomyopathy. Clin Cardiol 1992;15:739-742.

14. Day CP, Mccomb JM, Matthews J, Campbell RW. Reduction In QT dispersion by sotalol following myocardial infarction. EurHeart J 1991;12:423-427.

15. Grimm W, Steder U, Menz V, Hoffmann J, Maisch B. QT dispersion and arrhythmic events in idiopathic dilated cardiomyopathy. Am J Cardiol 1996;78:458-461.

16. Moreno-Navarrete JM, Ortega F, Serrano M, et al. Irisin is expressed and produced by human muscle and adipose tissue in association with obesity and insulin resistance. J Clin Endocrinol Metab 2013;98:769-78.

17. Icli A, Cure E, Cure MC, et al. Novel myokine: irisin may be an independent predictor for subclinic atherosclerosis in Behçet's disease. J Investig Med. 2016;64:875-881.

18. Kim SK, Choe JY, Park SH, Lee SW, Lee GH, Chung WT. Increased Insulin Resistance and Serum Resistin in Korean Patients with Behcet's Disease. Archives of Medical Research 2010;41:269-274.
19. Messedi M, Frigui M, Mahfoudh KB et al. Intima-media Thickness of Carotid Artery in Patients with Behcet's Disease. Archives of Medical Research. 2011;42:398-404

20. Dogan FB, Cicek D, Aydin S et al. Serum Preptin and Amylin Values in Psoriasis Vulgaris and Behçet's Patients. J Clin Lab Anal. 2016;30:165-8.

21. Lee WS, Kim TY. Is mean platelet volume increased in Behçet's disease with thrombosis? Tohoku J.Exp. Med. 2010;222:225-226.

22. Alan S, Tuna S, Türkoğlu EB. The relation of neutrophil to lymphocyte ratio, platelet to lymphocyte ratio and mean platelet volume with the presence and severity of Behçet's syndrome. Kaohsiung J Med Sci. 2015;31:62631.

23. Açıkgöz N, Karıncıoğlu Y, Ermiş N, et al.Increased mean platelet volume in Behçet's Disease with thrombotic tendency. Tohoku J. Exp. Med. 2010;221:119-123.

24. Aksoy ŞN, Savaş E, Sucu M, Kısacık B, Kul S, Zengün O. Association between red blood cell distribution width and disease activity in patients with Behçet's disease. J Int Med Res. 2015;43:765-73.

25. Özşeker B, Şahin C, Özşeker HS, Efe SC, Kav T, Bayraktar Y. The Role of Fecal Calprotectin in Evaluating Intestinal Involvement of Behçet's Disease Volume 2016. (doi: 10.1155/2016/5423043). 